\title{
PENGEMBANGAN KEMAMPUAN PEMECAHAN MASALAH DAN HABIT OF MIND MATEMATIS MAHASISWA MELALUI TEKNIK SELF-EXPLANATION
}

\author{
Iyon Maryono', Rosi Oktaviani Saputri' \\ 1. Prodi Pendidikan Matematika, Fakultas Tarbiyah dan Keguruan, UIN Sunan \\ Gunung Djati Bandung, Jl. A.H. Nasution No.105, Bandung, Indonesia \\ iyonmaryono@uinsgd.ac.id
}

Received: 28 Oktober 2019; Accepted: 6 November 2019; Published: 29 Desember 2019

\begin{abstract}
Abstrak
Tujuan penelitian ini adalah untuk menganalisis dampak dari pembelajaran dengan teknik self-explanation pada mahasiswa yang mengikuti kuliah geometri analitik terhadap kemampuan pemecahan masalah dan habit of mind matematis. Metode penelitian yang digunakan adalah eksperimen semu desain Nonequivalent Control Grup Design. Sampel pada penelitian ini terdiri dari dua kelas yaitu kelas dengan teknik selfexplanation (3o orang) dan kelas dengan model pembelajaran langsung (33 orang). Data yang diperoleh berupa tes kemampuan pemecahan masalah matematis dan skala habits of mind matematis. Hasil penelitian menunjukkan bahwa: Peningkatan kemampuan pemecahan masalah matematis mahasiswa yang memperoleh teknik self-explanation lebih baik dibandingkan dengan yeng memperoleh pembelajaran langsung; Pencapaian kemampuan pemecahan masalah matematis mahasiswa yang memperoleh teknik self-explanation lebih baik dibandingkan dengan yang memperoleh pembelajaran langsung berdasarkan tingkat Pengetahuan Awal Matematis (PAM); Mathematical Habit of Mind untuk dimensi: komitmen, kapabilitas dan kebijakan semuanya terkategori positif setelah memperoleh teknik self-explanation.
\end{abstract}

Kata kunci: Self-explanation, Kemampuan Pemecahan Masalah Matematis, Mathematical Habits of Mind

\begin{abstract}
The purpose of this study is to analyze the impact of learning with self-explanation techniques on students who take analytic geometry courses on mathematical problem solving abilities and mathematical habits of mind. The research method used is quasi-experimental design Nonequivalent Control Group Design. The sample in this study consisted of two classes, namely classes with self-explanation techniques (3o people) and classes with direct instruction models (33 people). The data obtained in the form of tests of mathematical problem solving ability and mathematical habits of mind scale. The results showed that: Increased mathematical problem solving abilities of students who obtained better self-explanation techniques compared to those who obtained direct learning; The achievement of students' mathematical problem solving abilities that obtain self-explanation technique is better than those who obtain direct learning based on the level of Early Mathematical Knowledge (PAM); Mathematical Habit of Mind for dimensions: commitment, capability and policy are all positively categorized after obtaining a self-explanation strategy.
\end{abstract}

Keywords: Self-explanation, Mathematical Problem-Solving Ability, Mathematical Habits of Mind 


\section{PENDAHULUAN}

Dalam pembelajaran matematika, pemecahan masalah dapat dipandang dari dua sisi, yaitu: pemecahan masalah sebagai kemampuan matematis, dan pemecahan masalah sebagai suatu model pembelajaran. Pemecahan masalah sebagai kemampuan matematis dalam tulisan ini disebut sebagai Kemampuan Pemecahan Masalah Matematis (KPMM). KPMM merupakan inti dari tujuan pembelajaran matematika, sebab matematika dipelajari sebagai alat untuk memecahkan masalah pada berbagai bidang. Hal ini sejalan dengan NCTM (2000:334) yang menyakakan bahwa masalah dan pemecahan masalah memainkan peran penting dalam pembelajaran tentang konten matematika dan dalam membantu peserta didik membuat koneksi pada seluruh area konten matematika.

Pentingnya KPMM berkonsekuensi pada kurikulum pendidikan matematika. Studi Schoenfeld (2007) menyiratkan bahwa pengembangan kurikulum pendidikan matematika harus kembali fokus pada pemecahan masalah. Sebagai konsekuensi selanjutannya, pembelajaran matematika di kelas harus dapat mengembangkan kemampuan pemecahan masalah.

Eksperimen dengan menggunakan berbagai model atau teknik pembelajaran telah banyak dilakukan untuk mengembangkan KPMM. Sebagai contoh, metode Moore yang berfokus pada berpikir dengan hanya menggunakan pengetahuan yang dimiliki mahasiswa dapat meningkatkan kemampuan pemecahan masalah pembuktian pada mata kuliah geometri analitik (Maryono, Dewi, \& Syaf, 2018). Hal ini sebagai optimalisasi kemampuan berpikir dan usaha mahasiswa sebelum pembelajaran di kelas. Strategi metakognitif meningkat secara signifikan dalam pencapaian pemecahan masalah matematis dan keterampilan metakognitif (Özsoy \& Ataman, 2017). Model pembelajaran kontekstual dapat meningkatkan kemampuan pemecahan masalah matematis (Surya \& Putri, 2017). Berdasarkan proses pembelajarannnya ketiga hasil penelitian ini mencoba mengeksplorasi kemampuan berpikir peserta didik melalui masalah yang dipertimbangkan dapat mencapai tujuan pembelajaran.
Eksperimen dengan mengintegrasikan teknologi informasi dan komunikasi dalam mengembangkan KPMM telah dilakukan pula. Sebagai contoh, teknik kolaborasi berbantuan komputer yang terdiri dari tiga fase utama: pengamatan, kolaborasi dan bimbingan semi-terstruktur dapat meningkatkan keterampilan pemecahan masalah dalam waktu yang relatif singkat (Lazakidou \& Retalis, 2010). Begitu pula teknik pemberian contoh melalui animasi cukup efektif untuk mengajar kemampuan pemecahan masalah matematis (Scheiter, Gerjets, \& Schuh, 2010). Dua penelitian ini menyiratkan bahwa kemampuan pemecahan masalah dapat berkembang melalui bimbingan terstruktur atas proses berpikir peserta didik, bimbingan terstruktur difasilitasi melalui integrasi teknologi informasi dan komunikasi.

Berdasarkan hasil penelitian yang telah dipaparkan, dapat disimpulkan bahwa proses pembelajaran untuk mengembangkan KPMM hendaknya mengoptimalkan pemikiran alamiah peserta didik disertai bimbingan terarah dari pendidik. Suatu teknik pembelajaran yang berusaha mengoptimalkan kemampuan berpikir mahasiswa yaitu teknik self-explanation. Hasil penelitian (Hodds, Alcock, \& Inglis, 2014) menyimpulkan bahwa sebuah buklet sederhana berisi pelatihan self-explanation, yang dirancang untuk memusatkan perhatian peserta didik pada hubungan logis dalam bukti matematis, dapat secara signifikan meningkatkan pemahaman bukti mereka.

Menurut Chi, et al. (1989) perbedaan dalam kemampuan peserta didik untuk menyelesaikan masalah mungkin timbul dari perbedaan dalam cara mereka memahami dan belajar dari teks (termasuk contoh solusi yang dikerjakan). Oleh karena itu diperlukan suatu teknik pembelajaran untuk mengungkap eksplanasi-diri setiap siswa. Dalam konteks belajar pemecahan masalah istilah selfexplanation mengacu pada aktivitas menghasilkan penjelasan kepada diri sendiri (Chi, et all, (1989). Tujuan self-explanation bukan sekedar untuk menghafal materi tetapi untuk memahami apa yang sedang dibaca atau dipelajari. Ditinjau dari pandangan ini, self-explanation adalah aktivitas membangun pengetahuan yang dihasilkan oleh dan diarahkan pada diri sendiri. Melalui teknik 
Pengembangan Kemampuan Pemecahan Masalah dan Habit Of Mind Matematis Mahasiswa

Melalui Teknik Self-Explanation

self-explanation dosen mendorong mahasiswa untuk menjelaskan fenomena dirinya sendiri terhadap hal yang mereka amati, pernyataan dosen dan buku teks, serta jawaban atas masalah (Siegler \& Lin, 2009) .

Pada perkembangan berikutnya, selfexplanation menjadi sebuah teknik pembelajaran yang melibatkan mahasiswa secara aktif dengan cara memahami sebuah contoh maslah melalui penjelasan yang mereka berikan, dosen memastikan mahasiswa memperhatikan materi secara bermakna sambil memantau secara efektif perkembangan pemahaman mahasiswa. Secara teortis dan empirik teknik eksplanasidiri dikembangkan oleh (Chi et al., 1989) dengan alasan bahwa eksplanasi-diri dapat mengungkapkan pemahaman mahasiswa dengan menunjukkan apakah mereka mengetahui atau tidak: (1) kondisi penerapan tindakan; (2) konsekuensi dari tindakan; (3) hubungan tindakan dengan tujuan; (4) hubungan tujuan dan tindakan terhadap hukum alam dan prinsip lainnya.

Sintaks teknik self-explanation yang digunakan dalam penelitian ini mengacu pada (McNamara, O'Reilly, Rowe, Boonthum, \& Levinstein, 2007) dengan modifikasi sesuai kebutuhan dalam pembelajaran matematika. Sintaks tersebut terdiri dari empat tahap, yaitu: (1) Monitoring Comprehension, tahap ini merupakan aktivitas mengetahui kelemahan dalam bidang kognitif mahasiswa. Selanjutnya menentukan tahapan yang akan diambil untuk perbaikan kelemahan yang telah diketahui. Oleh karena itu, sebelum memulai pembelajaran, dosen membangun kesadaran peserta didik akan kemampuan mereka sendiri, mencari respon terhadap materi yang akan disampaikan. (2) Paraphrasing, pada saat menemukan masalah yang tidak dimengerti, tahap paraphrasing adalah aktivitas menjelaskan dan mengomunikasikan permasalahan tersebut ke dalam bahasa sendiri dalam rangka memper mudah pemahaman terhadap masalah dan penentuan penyelesaian yang akan ditempuh. (3) Bridging Inferences, tahap ini merupakan aktivitas pembuatan keputusan melalui keterkaitan yang dihasilkan dari proses selama berpikir terhadap masalah yang dihadapi untuk memahaminya dan menjelaskan kepada diri sendiri. (4) Elaborating, tahap ini merupakan proses pengembangan keputusan sehingga timbul pilihan-pilihan dalam penentuan penyelesaian yang sama. Saat melakukan langkah tersebut mahasiswa akan mengemukakan hasil pemahamannya di hadapan kelas agar memperoleh langkah yang beraneka ragam dalam penyelesaian masalah.

Untuk mengukur KPMM dalam penelitian ini, digunakan indikator yang relevan dengan langkah-langkah pemecahan masalah Polya, yaitu: (1) memahami masalah; merencanakan penyelesaian; menyelesaikan masalah sesuai dengan rencana; (4) melakukan pengecekan kembali terhadap semua langkah yang telah dikerjakan (Polya, 1954).

Beberapa faktor yang mempengaruhi perkembangan KPMM di antaranya adalah faktor keyakinan, afeksi dan kebiasaan berfikir. Menurut (Buchanan, 1987) faktorfaktor seperti sikap, motivasi, dan sistem kepercayaan penting untuk kinerja pemecahan masalah. Hal ini dikuatkan oleh temuan penelitian (Lerch, 2004) yaitu: (1) Sistem kepercayaan seseorang berdampak pada bagaimana mereka mendekati suatu masalah; (2) Kurangnya kepercayaan diri dan kurangnya keberhasilan sebelumnya mendorong keputusan cepat untuk berhenti bekerja menyelesaikan masalah; (3) Gagal menyelesaikan masalah karena ketergantungan terhadap strategi solusi untuk jenis masalah tertentu. Selain itu, faktor keyakinan dan afektif yang perlu diperhatikan dalam pemecahan masalah yakni memahami sifat dan dampak dari keyakinan dan afektif yang produktif dan tidak produktif terhadap pembelajaran dan pengajaran pemecahan masalah (Chapman, 2015).

Faktor kebiasaan berpikir matematis (Mathematical Habits of Mind) atau MHoM penting pula diperhatikan dalam mengembangkan KPMM. Gagasan tentang MHoM ini telah diperkenalkan untuk menekankan perlunya membantu siswa berpikir tentang matematika seperti yang dilakukan para ahli matematika (Lim \& Selden, 2009). Aspek MHoM meliputi penalaran dengan kesinambungan, melihat kasus-kasus ekstrem, melakukan eksperimen pemikiran, dan menggunakan abstraksi yang 
digunakan matematikawan dalam pekerjaan mereka (Mark, Cuoco, Goldenberg, \& Sword, 2010). Penelitian (Mark et al., 2010) menemukan bahwa menggunakan MHoM dalam penyelenggaraan pendidikan dapat membawa koherensi yang asli dan sering mengejutkan dalam kurikulum.

Terdapat 16 Habits of Mind yang diidentifikasi oleh (Costa \& Calick, 2009), namun dalam penelitian ini diambil empat aspek yang terkategori sangat relevan dengan pemecahan masalah matematis, yaitu: (1) Persisting (Berteguh Hati), indikator untuk mengukur persisting terdiri dari: tekun dalam belajar; mendemonstrasikan metode-metode sistematis dalam menganalisis permasalahan; membedakan gagasangagasan pemecahan maslah yang berhasil dan tidak, dan terbiasa menggunakan berbagai cara untuk menyelesaikan tugas atau permasalahan. (2) Thinking about Thinking (Metakognisi), untuk mengukur thinking about thinking digunakan indikator: terbiasa bekerja atau bertindak sesuai rencana; terbiasa sadar akan pemikiran dan tindakannya; terbiasa merancang strategi dalam memunculkan informasi yang diperlukan untuk memecahkan masalah dan terbiasa menggambarkan langkah-langkah yang digunakannya untuk melakukan pemecahan masalah. (3) Thinking Flexibly (Berpikir Fleksibel), untuk mengukur thinking flexibly digunakan indikator: terbiasa berpikiran terbuka; terbiasa memiliki banyak ide dan gagasan mengenai suatu hal, terbiasa mengubah sudut pandang atau pemikiran saat mendapat informasi baru atau tambahan dan terbiasa menggunakan berbagai macam cara pemecahan masalah untuk menyelesaikan masalah yang sama. (4) Applying Past Knowledge to New Situation (Menggunakan Pengetahuan Masa Lalu pada Situasi Baru), mahasiswa yang memiliki kebiasaan ini memiliki indikator: mampu mengambil makna dari pengalamannya pada situasi baru. Ketika dihadapkan dengan masalah baru yang membingungkan, mahasiswa cenderung menghubungkannya dengan pengalaman masa lampau yang dimilikinya untuk menyelesaikan masalah. Selanjutnya keempat aspek habit of mind tersebut dalam penelitian ini disebut MHoM.
Untuk memperoleh aspek yang lebih rinci dan untuk mengetahui kesetaraan kemampuan mahasiswa antara kelas eksperimen dan kelas kontrol pada penelitian ini dipertimbangkan Penetahuan Awal Matemtis (PAM). PAM mahasiswa digolongkan menjadi tiga kategori, yaitu tinggi (T), sedang (S) dan rendah (R). Penggolongan PAM dianggap penting dalam proses pembelajaran agar dosen dapat mengetahui keragaman tingkat berpikir mahasiswa dan dapat menyajikan pembelajaran yang mampu mengatasi keragaman individu.

Uraian dimuka, menggiring pada tiga rumusan masalah dalam penelitian ini, yaitu: (1) Apakah peningkatan kemampuan pemecahan masalah matematis mahasiswa yang menggunakan teknik self-explanation lebih baik dibanding mahasiswa yang menggunakan pembelajaran langsung?; (2) Apakah pencapaian kemampuan pemecahan masalah matematis mahasiswa yang menggunakan teknik self-explanation lebih baik dibanding mahasiswa yang menggunakan pembelajaran langsungl berdasarkan tingkat Pengetahuan Awal Matematika (PAM) yang kategorinya tinggi, sedang dan rendah?; (3) Berada pada kategori apa habits of mind matematis mahasiswa setelah pembelajaran menggunakan teknik self-explanation?

\section{METODE PENELITIAN}

Penelitian ini menggunakan metode eksperimen semu dengan desain kelompok non-ekuivalen pretes-postes seperti terlihat pada Tabel 1.

Tabel 1 Desain Penelitian

$\begin{array}{ccc}\mathrm{O} & \mathrm{X} & \mathrm{O} \\ \mathrm{O} & \mathrm{O}\end{array}$

Keterangan:

$\mathrm{X}$ : Pemberian teknik self-explanation

$\mathrm{O}$ : Pretest dan Posttest

Desain penelitian pada Tabel 1 menunjukkan bahwa variabel bebas penelitian ini adalah teknik self-explanation, sedangkan variabel terikatnya adalah KPMM. Postes digunakn untuk menganalisis pencapaian KPMM, sedangkan peningkatan KPMM dianalisis melalui perbedaan hasil Pretes dan Postes. 
Sampel diambil dari populasi mahasiswa yang mengambil mata kuliah geometri analitik pada Program Studi Pendidikan Matematika di salah satu universitas di Bandung tahun akademik 2018-2019. Sampel terdiri dari dua kelas, yaitu kelas eksperimen sebanyak 30 orang mahasiswa yang memperoleh teknik self-explanation, dan kelas kontrol sebanyak 33 orang mahasiswa yang memperoleh model pembelajaran langsung (direct instruction).

Instrumen utama yang digunakan dalam penelitian ini yaitu soal tes KPMM sebanyak empat butir dan skala MHoM sebanyak 30 butir. Berdasarkan hasil uji validitas butir, keempat soal tes KPMM memiliki validitas tinggi, begitu pula reliabilitas soal tes KPMM tergolong tinggi. Secara rinci validitas butis dan reliabilitas tes KPMM disajikan pada Tabel 2.

Tabel 2 Validitas Butir dan Reliabilitas Soal KPMM

\begin{tabular}{cccc}
\hline No. & \multicolumn{2}{c}{ Validitas } & \multirow{2}{*}{ Reliabilitas } \\
\cline { 2 - 3 } Soal & Nilai & Interpretasi & \\
\hline 1 & 0,77 & Tinggi & \\
\hline 2 & 0,95 & Sangat Tinggi & 0,845 \\
\cline { 1 - 2 } 3 & 0,86 & Sangat Tinggi & (Sangat \\
\hline 4 & 0,92 & Sangat Tinggi & Tinggi) \\
\hline
\end{tabular}

Skala MHoM dibuat untuk mengetahui kualitas MHoM mahasiswa setelah memperoleh pembelajaran menggunakan teknik self-explanation. Skala MHoM mahasiswa terdiri dari 30 butir pernyataan dengan 14 pernyataan positif dan 16 pernyataan negatif yang diberikan setelah pembelajaran. Mahasiswa memilih salah satu dari empat pilihan dari setiap pertanyaan. Pilihan tersebut adalah Sangat Setuju (SS), Setuju (S), Tidak Setuju (TS) dan Sangat Tidak Setuju (STS). Sebelum digunakan skala MHoM ini diuji validitas muka dan validitas isinya oleh dua orang ahli pendidika matematika. Hasil uji validitas ini menunjukkan bahwa skala MHoM telah layak digunakan untuk mengukur skala MHoM mahasiswa.

\section{HASIL DAN PEMBAHASAN}

\section{(1) Peningkatan Pemecahan Masalah Matematis}

Pengembangan Kemampuan Pemecahan Masalah dan Habit Of Mind Matematis Mahasiswa Melalui Teknik Self-Explanation Dalam rangka melihat perbedaan peningkatan KPMM antara kelas yang mendapatkan teknik self-explanation dan kelas yang mendapatkan model pembelajaran langsung, maka dilakukan pengolahan data hasil pretes dan postes KPMM. Data tersebut berupa nilai gain ternormalisasi ( $\mathrm{N}$-gain). Setelah dilakukan uji normalitas dan homogenitas varian terhadap data $\mathrm{N}$-gain, maka diperoleh bahwa data N-gain berdistribusi normal dan memiliki varians yang homogen.

Setelah asumsi normalitas dan homogeitas terpenuhi, selanjutnya dilakukan uji tindependent. Uji t-independent data $\mathrm{N}$-gain dilakukan untuk menguji perbedaan peningkatan KPMM antara kelas yang mendapatkan teknik self-explanation dan kelas yang mendapatkan model pembelajaran langsung (Direct Instruction). Hasil uji tindependent disajikan pada Tabel 3.

Tabel 3 Hasil Uji t-independent Data N-gain t-test For Equality of Means

\begin{tabular}{cccc}
\hline $\mathrm{T}$ & $\mathrm{dF}$ & $\begin{array}{c}\text { Sig. } \\
(2-\text { tailed })\end{array}$ & $\begin{array}{c}\text { Mean } \\
\text { Difference }\end{array}$ \\
\hline 3,244 & 61 & 0,002 & 0,145 \\
\hline
\end{tabular}

Berdasarkan Tabel 5, nilai Sig. (2-tailed) $(0,002)<0,05$. Kondisi ini dapat diartikan bahwa pada taraf signifikan $\alpha=0,05$ peningkatan KPMM mahasiswa yang memperoleh teknik self-explanation lebih baik dibandingkan dengan mahasiswa yang memperolah model pembelajaran langsung. Dengan demikian, kondisi ini menjawab rumusan masalah pertama yakni melalui teknik self-explanation KPMM mahasiswa berhasil meningkatkan secara signifikan. Hal ini sesuai dengan penelitian (Hodds et al., 2014) yang berhasil pula meningkatkan pemecahan masalah pembuktian setelah mahasiswa mengikuti pelatihan selfexplanation. Hal ini cukup logis, karena teknik self-explanation dirancang agar mahasiswa mencurahkan pemikiran orisinalnya (paraphrasing) sehingga diperoleh keputusan (Bridging Inferences) yang kemudian didiskusikan sehinggga 
kesalahan-kesalahan pemikiran dapat dihindari (Elaborating).

\section{(2) Pencapaianan Pemecahan Masalah Matematis}

Untuk mengetahui mana pencapaian KPMM yang lebih baik antara mahasiswa yang menggunakan teknik self-explanation dengan mahasiswa yang menggunakan pembelajaran langsung (Direct Instruction) ditinjau berdasarkan tingkat PAM (Tinggi, Sedang, Rendah) dilakukan uji Anova dua jalur. Adapun asumsi-asumsi yang harus dipenuhi yaitu uji normalitas dan uji homogenitas varians yang didapat dari data posttest mahasiswa berdasarkan kategori PAM harus terkategori normal dengan varian yang homogen.

Tabel 4 Uji Normalitas Data Posttest Berdasarkan Tingkat PAM

\begin{tabular}{cccc}
\hline \multirow{2}{*}{ Kelas } & \multicolumn{3}{c}{ Kolmogorov } \\
& Smirnov \\
\cline { 2 - 4 } & Statistic & df & Sig. \\
\hline SE-T & 0,129 & 30 & 0,200 \\
\hline SE-S & 0,129 & 30 & 0,200 \\
\hline SE-R & 0,129 & 30 & 0,200 \\
\hline DI-T & 0,256 & 7 & 0,183 \\
\hline DI-S & 0,111 & 21 & 0,200 \\
\hline DI-R & 0,329 & 5 & 0,81 \\
\hline
\end{tabular}

Keterangan:

SE-T: Kelas Self-Explanation dengan kategori PAM Tinggi

SE-S: Kelas Self-Explanation dengan kategori PAM Sedang

SE-R: Kelas Self-Explanation dengan kategori PAM Rendah

DI-T: Kelas Direct Instruction dengan kategori PAM Tinggi

DI-S: Kelas Direct Instruction dengan kategori PAM Sedang

DI-R: Kelas Direct Instruction dengan kategori PAM Rendah

Pada Tabel 4 terlihat bahwa semua nilai Sig. dari data nilai posttest kelas teknik selfexplanation maupun kelas pembelajaran langsung berdasarkan tingkat PAM lebih dari 0,05 hal ini menunjukkan bahwa data posttest berdistribusi normal. Untuk menguji prasyarat yang kedua yaitu data posttest harus berasal dari data yang memiliki varians homogen, maka akan dilakukan uji homogenitas.

Tabel 5 Uji Homogenitas Data Posttest Berdasarkan Tingkat PAM

\begin{tabular}{cccc}
\hline $\begin{array}{c}\text { Levene } \\
\text { Statistic }\end{array}$ & $\mathbf{d f}_{\mathbf{1}}$ & $\mathbf{d f}_{\mathbf{2}}$ & Sig. \\
\hline 1,105 & 2 & 60 & 0,338 \\
\hline
\end{tabular}

Berdasarkan Tabel 5 terlihat bahwa nilai Sig. dari data posttest yaitu $0,338>0,05$ yang artinya varians data posttest berdasarkan tingkat PAM memiliki varians yang homogen. Karena kedua asumsi terpenuhi, maka analisis dilanjutkan dengan uji Anova dua jalur. Hasil uji Anova dua jalur disajikan pada Tabel 6.

Tabel 6 Uji Anova Dua Jalur Data Posttest Berdasarkan Tingkat PAM

\begin{tabular}{llcccc}
\hline Source & $\begin{array}{l}\text { Type III } \\
\text { Sum of } \\
\text { Square }\end{array}$ & Df & $\begin{array}{c}\text { Mean } \\
\text { Square }\end{array}$ & F & Sig. \\
\hline Teknik & 1250,024 & 1 & 1250,024 & 8,154 & $\mathbf{o , 0 0 6}$ \\
\hline $\begin{array}{l}\text { Kategori } \\
\text { PAM }\end{array}$ & 1357,006 & 2 & 678,503 & 4,426 & $\mathbf{0 , 0 1 6}$ \\
\hline $\begin{array}{l}\text { Teknik } \\
\text { PAM }\end{array}$ & 97,056 & 2 & 48,528 & 0,317 & $\mathbf{0 , 7 3 0}$ \\
\hline
\end{tabular}

Dengan memperhatikan nilai sig. pada Tabel 6 dan mengambil taraf signifikan $\alpha=0,05$ maka dapat diambil beberapa kesimpulan sebagai berikut:

(1) Nilai Sig. sebesar 0,006 < 0,05, menunjukkan bahwa pencapaian KPMM mahasiswa yang menggunakan teknik self-explanation lebih baik dibandingkan dengan mahasiswa yang memperoleh pembelajaran langsung ditinjau secara keseluruhan.

(2) Nilai Sig. sebesar 0,016 < 0,05, menunjukkan bahwa KPMM mahasiswa yang menggunakan teknik selfexplanation lebih baik dibandingkan dengan mahasiswa yang memperoleh pembelajaran langsung ditinjau berdasarkan tingkat PAM dengan kategori tinggi, sedang, dan rendah.

(3) Nilai Sig. sebesar 0,730 > 0,05, menunjukkan bahwa tidak terdapat efek interaksi antara teknik pembelajaran dan tingkat PAM secara bersama-sama terhadap pencapaian KPMM.

Untuk mengetahui perbedaan pencapaian KPMM mahasiswa secara lebih rinci berdasarkan kategori PAM tinggi, sedang, dan rendah, yakni kelompok mahasiswa pada 
kategori PAM yang mana yang berbeda, maka dilakukan uji lanjut Post Hoc Tukey. Adapun hasil pengujiannya disajikan pada Tabel 7 .

Tabel 7 Uji Post Hoc Tukey Data Posttest Berdasarkan PAM

\begin{tabular}{cccc}
\hline \multirow{2}{*}{$\begin{array}{c}\text { (I) } \\
\text { PAM }\end{array}$} & $\begin{array}{c}\text { (J) } \\
\text { PAM }\end{array}$ & $\begin{array}{c}\text { Mean } \\
\text { Difference } \\
\text { (I-J) }\end{array}$ & Sig. \\
\hline \multirow{2}{*}{ Tinggi } & Sedang & 9,6448 & 0,063 \\
\cline { 2 - 4 } & Rendah & 15,9394 & 0,016 \\
\hline \multirow{2}{*}{ Sedang } & Tinggi & $-9,6448$ & 0,063 \\
\cline { 2 - 4 } & Rendah & 6,2946 & 0,354 \\
\hline \multirow{2}{*}{ Rendah } & Tinggi & $-15,9394$ & 0,016 \\
\cline { 2 - 4 } & Sedang & $-6,2946$ & 0,354 \\
\hline
\end{tabular}

Dengan mempertimbangkan nilai sig. pada Tabel 7 dan mengambil taraf signifikan $\alpha=$ 0,05 , maka dapat diambil beberapa kesimpulan sebagi berikut:

(1) Nilai Sig. untuk pasangan PAM mahasiswa tinggi dan mahasiswa sedang yaitu $0,063>0,05$. Hal ini berarti pencapaian KPMM mahasiswa PAM tinggi tidak lebih baik dibanding mahasiswa dengan PAM sedang.

(2) Nilai Sig. untuk pasangan PAM mahasiswa tinggi dan rendah yaitu 0,016 $<$ 0,05. Artinya pencapaian KPMM mahasiswa dengan PAM tinggi lebih baik dibanding mahasiswa dengan PAM rendah.

(3) Nilai Sig. untuk pasangan PAM sedang dan tinggi yaitu $0,063>0,05$. Artinya pencapaian KPMM mahasiswa PAM sedang tidak lebih baik dibanding mahasiswa dengan PAM tinggi.

(4) Nilai Sig. untuk pasangan PAM sedang dan rendah yaitu $0,354>0,05$. Artinya pencapaian KPMM mahasiswa dengan PAM sedang tidak lebih baik dibanding mahasiswa dengan PAM rendah.

(5) Nilai Sig. untuk pasangan PAM rendah dan tinggi yaitu $0,016<0,05$. Artinya pencapaian KPMM mahasiswa dengan PAM rendah lebih baik dibanding mahasiswa dengan PAM tinggi.

(6) Nilai Sig. untuk pasangan PAM rendah dan sedang yaitu $0,354>0,05$. Artinya pencapaian KPMM mahasiswa dengan PAM rendah tidak lebih baik dibanding mahasiswa dengan PAM sedang.
Pengembangan Kemampuan Pemecahan Masalah dan Habit Of Mind Matematis Mahasiswa

Melalui Teknik Self-Explanation Interaction plot perbedaan pencapaian KPMM mahasiswa disajikan pada Gambar 1. Estimated Marginal Means of Posttest

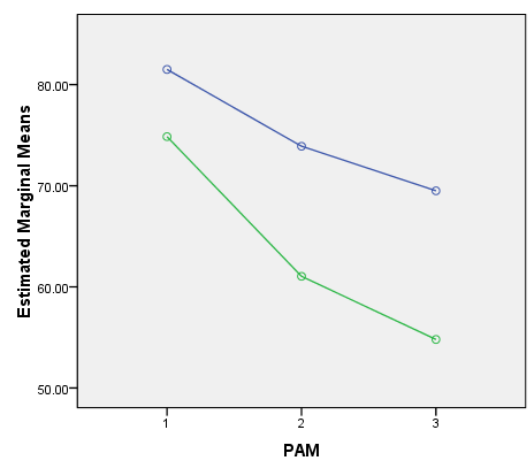

Gambar 1 Interaksi antara PAM Mahasiswa dan TeknikPembelajaran terhadap KPMM Berdasarkan Gambar 1 terdapat beberapa informasi, diantaranya:

(1) Kelas yang menggunakan teknik selfexplanation dengan kategori PAM tinggi lebih baik dari kategori sedang dan rendah serta lebih baik dari kelas yang menggunakan pembelajaran langsung dengan kategori PAM tinggi, sedang dan rendah.

(2) Kelas yang menggunakan teknik selfexplanation dengan kategori PAM sedang lebih baik dari kategori rendah serta lebih baik dari kelas yang menggunakan pembelajaran langsung dengan kategori PAM sedang, dan rendah.

(3) Kelas yang menggunakan teknik selfexplanation dengan kategori PAM rendah tidak lebih baik dari kategori tinggi dan sedang serta lebih baik dari kelas yang menggunakan pembelajaran langsung dengan kategori PAM sedang dan rendah.

Berdasarkan uji Anova Dua Jalur dan uji Post Hoc Tukey terhadap pencapaian KPMM mahasiswa, maka teknik self-explanation cukup efektif dalam pembelajaran yang fokus pada pemecahan masalah ditinjau secara keseluruhan. Adanya fenomena yang menunjukkan ketidakberhasilan teknik selfexplanation mengungguli pembelajaran langsung berdasarkan kategori PAM, yaitu pada: Tinggi-Sedang; Sedang-Tinggi; SedangRendah dan Rendah-Sedang seperti yang terlihat pada Tabel 7 beseta kesimpulannya, mungkin karena tipisnya perbedaan pencapaian. Hal ini dikuatkan oleh RittleJohnson, Loehr, \& Durkin (2017) yang menyimpulkan bahwa teknik self-explanation mendorong dan mengarah ke peningkatan 
kecil ke sedang dalam pengetahuan prosedural, pengetahuan konseptual dan transfer prosedural ketika dinilai segera setelah intervensi.

\section{(3) Kategori Habits of Mind Matematis Mahasiswa Setelah Memperoleh Teknik Self- Expanation}

Untuk mengetahui kategori Mathematical Habits of Mind (MHoM) mahasiswa setelah memperoleh teknik self-explanation, dalam penelitian ini dipilih tiga dimensi MHoM yang terdiri dari sembilan karakteristik seperti pada Tabel 8.

Tabel 8 Dimensi dan Karakteristik MHoM

\begin{tabular}{|c|c|}
\hline $\begin{array}{l}\text { Dimensi } \\
\text { MHoM }\end{array}$ & Karakteristik \\
\hline \multirow{4}{*}{ Komitmen } & $\begin{array}{l}\text { Mengeksplorasikan ide-ide } \\
\text { matematis }\end{array}$ \\
\hline & Berteguh hati \\
\hline & Berpikir fleksibel \\
\hline & Bersedia terus belajar \\
\hline \multirow[t]{2}{*}{ Kapabilitas } & $\begin{array}{l}\text { Bertanya pada diri sendiri } \\
\text { apakah terdapat "sesuatu } \\
\text { yang lebih" dari aktivitas } \\
\text { matematika yang telah } \\
\text { dilakukan (generalisasi) }\end{array}$ \\
\hline & $\begin{array}{l}\text { Menerapkan pengetahuan } \\
\text { sebelumnya di situasi baru }\end{array}$ \\
\hline \multirow{3}{*}{ Kebijakan } & $\begin{array}{l}\text { Mengidentifikasikan strategi } \\
\text { pemecahan masalah yang } \\
\text { dapat diterapkan untuk } \\
\text { menyelesaikan masalah }\end{array}$ \\
\hline & $\begin{array}{l}\text { Merefleksikan kebenaran } \\
\text { jawaban }\end{array}$ \\
\hline & $\begin{array}{l}\text { Mempertanyakan dan } \\
\text { menemukan permasalahan }\end{array}$ \\
\hline
\end{tabular}

Rata-rata skor MHoM ditinjau berdasarkan tiga dimensinya, yaitu komitmrn, kapabilitas dan kebijaksanaan terlihap pada Tabel 9.

Tabel 9 Rata-rata Skor MHoM Berdasarkan Dimensinya

\begin{tabular}{ccc}
\hline $\begin{array}{c}\text { Dimensi } \\
\text { MHoM }\end{array}$ & $\begin{array}{c}\text { Rata-rata } \\
\text { Skor MHoM }\end{array}$ & $\begin{array}{c}\text { Skor } \\
\text { Netral }\end{array}$ \\
\cline { 1 - 2 } Komitmen & 2,79 & \\
\cline { 1 - 2 } Kapabilitas & 2,58 & \\
\cline { 1 - 2 } Kebijaksanaan & 2,96 & \\
\hline
\end{tabular}

Berdasarkan Tabel 11, komitmen, kapabilitas dan kebijaksanaan mahasiswa memiliki rata- rata skor masing-masing 2,$79 ; 2,58$ dan 2,96. Hal ini dapat diartikan bahwa setelah mengikuti teknik self-explanation komitmen, kapabilitas dan kebijaksanaan mahasiswa terkategori positif, sebab rata-rata skor ketiga dimensi MHoM tersebut lebih tinggi dari skor netralnya.

\section{KESIMPULAN}

Berdasarkan uraian yang telah dipaparkan sebelumnya, dapat diperoleh beberapa kesimpulan. Pertama, peningkatan Kemampuan Pemecahan Masalah Matematis (KPMM) mahasiswa yang memperoleh teknik self-explanation lebih baik dibandingkan dengan mahasiswa yang memperoleh pembelajaran langsung. Kedua, pencapaian KPMM mahasiswa yang memperoleh teknik self-explanation lebih baik dibandingkan dengan mahasiswa yang memperoleh pembelajaran langsung ditinjau berdasarkan kelas secara keseluruhan. Tiga, dintinjau berdasarkan Pengetahuan Awal Matematis (PAM) dengan kategori tinggi, sedang dan rendah, diperoleh hasil bahwa pencapaian KPMM pada kelas teknik self-explanation lebih baik dibandingkan dengan mahasiswa yang memperoleh pembelajaran langsung pada kategori tinggi dan rndah. Empat, tidak terdapat efek interaksi antara teknik pembelajaran dan tingkat PAM secara bersama-sama terhadap pencapaian KPMM. Lima, Mathematical Habits of Mind (MHoM) mahasiswa setelah menggunakan teknik selfexplanation terkategori positif.

\section{REFERENSI}

Buchanan, N. K. (1987). Factors contributing to mathematical problem-solving performance: An exploratory study. Educational Studies in Mathematics, 18(4), 399-415.

Chapman, O. (2015). Mathematics teachers' knowledge for teaching problem solving. LUMAT (2013-2015 Issues), 3(1), 19-36.

Chi, M. T., Bassok, M., Lewis, M. W., Reimann, P., \& Glaser, R. (1989). Selfexplanations: How students study and use examples in learning to solve problems. Cognitive Science, 13(2), 145-182. 
Costa, A. L., \& Calick, B. (2009). Habits of Mind Across the Curriculum: Practical and Creative Strategies for Teachers. Virginia: Association for Supervision and Curriculum Development.

Hodds, M., Alcock, L., \& Inglis, M. (2014). Self-explanation training improves proof comprehension. Journal for Research in Mathematics Education, 45(1), 62-101.

Lazakidou, G., \& Retalis, S. (2010). Using computer supported collaborative learning strategies for helping students acquire self-regulated problem-solving skills in mathematics. Computers \& Education, 54(1), 3-13.

Lerch, C. M. (2004). Control decisions and personal beliefs: Their effect on solving mathematical problems. The Journal of Mathematical Behavior, 23(1), 2136.

Lim, K. H., \& Selden, A. (2009). Mathematical habits of mind. 1576-1583.

Mark, J., Cuoco, A., Goldenberg, E. P., \& Sword, S. (2010). Developing Mathematical Habits of Mind. Mathematics Teaching in the Middle School, 15(9), 505-509.

Maryono, I., Dewi, S. A. L., \& Syaf, A. H. (2018). Karakteristik pencapaian kemampuan pembuktian dan kepercayaan diri mahasiswa melalui metode moore. Jurnal Analisa, 4(2), $72-82$.

McNamara, D. S., O’Reilly, T., Rowe, M., Boonthum, C., \& Levinstein, I. B. (2007). ISTART: A web-based tutor that teaches self-explanation and metacognitive reading strategies. Reading Comprehension Strategies: Theories, Interventions, and Technologies, 397-421.

NCTM. (2000). Principles and Standards for School Mathematics. Reston: The National Council of Teachers of Mathematics, Inc.

Özsoy, G., \& Ataman, A. (2017). The effect of metacognitive strategy training on mathematical problem solving achievement. International Electronic
Pengembangan Kemampuan Pemecahan Masalah dan Habit Of Mind Matematis Mahasiswa Melalui Teknik Self-Explanation Journal of Elementary Education, 1(2), 67-82.

Polya, G. (1954). Introduction and Analogy in Mathematics. London: Princeton University Press.

Rittle-Johnson, B., Loehr, A. M., \& Durkin, K. (2017). Promoting self-explanation to improve mathematics learning: A meta-analysis and instructional design principles. $Z D M, 49(4), 599-611$.

Scheiter, K., Gerjets, P., \& Schuh, J. (2010). The acquisition of problem-solving skills in mathematics: How animations can aid understanding of structural problem features and solution procedures. Instructional Science, 38(5), 487-502.

Schoenfeld, A. H. (2007). Problem solving in the United States, 1970-2008: Research and theory, practice and politics. ZDM, 39(5-6), 537-551.

Siegler, R. S., \& Lin, X. (2009). Selfexplanations promote children's learning. Metacognition, Strategy Use, and Instruction, 85-113.

Surya, E., \& Putri, F. A. (2017). Improving Mathematical Problem-Solving Ability and Self-Confidence of High School Students through Contextual Learning Model. Journal on Mathematics Education, 8(1), 85-94. 